\title{
MEASURING RELATIVE EFFICIENCY OF SECONDARY EDUCATION IN SELECTED EU AND OECD COUNTRIES: THE CASE OF SLOVENIA AND CROATIA
}

\author{
Aleksander ARISTOVNIK ${ }^{\mathrm{a}}$, Alka OBADIĆ \\ ${ }^{a}$ University of Ljubljana, Ljubljana, Slovenia \\ ${ }^{\mathrm{b}}$ Faculty of Economics and Business, University of Zagreb, Zagreb, Croatia
}

Received 02 March 2012; accepted 06 April 2013

\begin{abstract}
This article continues on a number of previous studies by other scientists in investigating secondary education efficiency by applying a non-parametric methodology. In this respect, the purpose of the article is to review some previous studies on measuring the efficiency of public (secondary) education sector as well as some conceptual and methodological issues of a non-parametric approach. Most importantly, the Data Envelopment Analysis (DEA) technique is presented and then applied to a wide range of EU and OECD countries, including Slovenia and Croatia, to evaluate the technical efficiency of secondary education. The empirical results show that technical efficiency in secondary education varies significantly across the great majority of EU and OECD countries. Both Slovenia and Croatia show a relatively high level of technical inefficiency in their secondary education as they respectively only rank in the third and fourth quartiles among selected countries. Therefore, rationalising public secondary education spending is strongly recommended with possible redirecting of some excessive resources to the tertiary education sector.
\end{abstract}

Keywords: secondary education, technical efficiency, DEA, Slovenia, Croatia, EU, OECD.

JEL Classification: C14, C61, H52, I21.

\section{Introduction}

Education is one of the most important government expenditure items in the most developed economies and there is a rationale for this amount (Oganisjana, Koke 2012; Čadež 2013). Indeed, the public sector mainly finances and manages the Croatian and Slovenian educational systems, and this is also the case in most European and emerging market economies (Mencinger, Aristovnik 2013). In the 2001-2008 period, the overall

Corresponding author Aleksander Aristovnik

E-mail: aleksander.aristovnik@fu.uni-lj.si 
proportion of GDP given over to education in the EU-27 remained stable at around 5\%. This stable European average hides disparities between countries, some of which experienced significant changes during the period. In Bulgaria, Cyprus and Iceland, the proportion of GDP allocated to education increased by over 20\% between 2001 and 2008 and by more than $30 \%$ in Malta and Ireland over the same period. Significant growth - above $10 \%$ - also occurred in the United Kingdom. The stability in the overall figures for 2001-2008 also masks spending disparities at the different levels of education. Expenditure rose by more than $5 \%$ on pre-primary and tertiary education as a proportion of GDP in the 2001-2008 period. In contrast, expenditure on secondary education decreased slightly (Eurostat 2012). However, due to the relatively high amount and importance of this type of government expenditure, the measurement of its efficiency should be high on the policy agenda of every government (Keseljevic 2007; Verbič et al. 2011).

Many empirical studies on the performance and efficiency of the public sector (at national level) that applied non-parametric methods (e.g. data envelopment analysis - DEA) find significant divergence of efficiency across countries. Studies include notably Gupta and Verhoeven (2001) for education and health in Africa, Clements (2002) for education in Europe, St. Aubyn (2003) for education spending in the OECD, Afonso et al. $(2005,2006)$ for the public sector performance expenditure in the OECD and in emerging markets, Afonso and St. Aubyn (2005, $2006 \mathrm{a}, \mathrm{b})$ for efficiency in providing health and education in OECD countries. Gunnarsson and Mattina (2007) assess the efficiency of public spending by comparing expenditure on health, education and social protection in Slovenia. In addition, Afonso et al. (2008) assess the efficiency of public spending for redistributing income. Other authors (e.g. Mandl et al. 2008; Jafarov, Gunnarsson 2008) have tried to improve on the work of Afonso et al. (2005). Moreover, Grasskopf and Moutray (2001), Johnes (2006), Castano and Cabanda (2007), Jafarov and Gunnarsson (2008), Cherchye et al. (2010), Obadić and Aristovnik (2011), J.-K. Chen and I.-S. Chen (2011), Thieme et al. (2012) and Aristovnik (2012a, b) have focused on measuring efficiency or quality (see Stukalina 2012) in the education sector.

Since very insightful, cross-country analyses, particularly for the secondary education sector, are rarely used for policy analysis, we will apply the DEA approach to several EU (plus Croatia) and OECD countries, with a special focus on Slovenia and Croatia in the rest of the article. DEA is chosen here because it is more common for measuring technical efficiency ${ }^{1}$ as it can be applied to multi-input and multi-output variables. The analysis includes $31 \mathrm{EU}$ (plus Croatia) and OECD countries in 1999-2007 period. The article is divided into four parts. An international comparison of secondary education in Croatia and Slovenia is presented in the second part. Research results of the DEA analysis are provided in the third part. Finally, the article ends with a conclusion.

\footnotetext{
1 Technical efficiency is the effectiveness with which a given set of inputs is used to produce an output. This means getting the most production (output/outcome) from available resources (inputs).
} 


\section{Secondary education in Slovenia and Croatia: some international comparisons}

\subsection{General overview}

Public expenditure by level of education differs from country to country partly because it is affected by structural differences in education systems, including the duration of each level of education and the overall length of compulsory education. Further, caution must be exercised in interpreting the data in many countries because it is not always possible to break expenditure down fully by educational level.

In nearly all European countries, the total public expenditure allocated to secondary education represents a greater proportion of GDP than spending on any other educational levels, with the maximum proportion in any country being 3.2\% (in Cyprus and Malta). In Spain, Poland, Slovakia, Liechtenstein and Croatia, it is below 2\% of GDP (Eurostat 2012). Education expenditure is largely financed from public funds. Indeed, in all countries, public financing meets at least $69 \%$ of education expenditure, taking all educational levels together. In Belgium, Estonia, Malta, Finland, Sweden and Norway, the share of public funding is higher at around 95\% (Eurostat 2012).

Secondary education in Croatia is provided by secondary school institutions and other legal persons and incorporates various types and forms of instruction, education, qualification and training that are carried out according to the provisions of the Primary and Secondary School Education Act. There is a large number of young people in Croatia - as a member of the group of European countries with the shortest compulsory schooling - who do not enrol in high school after finishing elementary school and, of those who do enrol in it, as few as $69.5 \%$ finish it ${ }^{2}$. The young population made up of low-qualified persons (people who have finished elementary school) faces slim or no chances at all of finding a job, leaving them without a basis for settling their existential issues and depriving them, at an early age, of the fundamental rights of democratic society - the right to employment and the right to social benefits. In response, on 21 June 2007, the Croatian Parliament adopted the National Programme of Measures for the Introduction of Compulsory Secondary Education (Official Gazzette 2007).

Secondary schools in Croatia are divided into Gymnasiums (general or specialised), Vocational or trade schools (technical, industrial, trade and others) and Art schools (music, dance, visual arts and others). In Slovenia post-compulsory education begins with upper-secondary education. It is divided into general upper-secondary education, technical upper-education and vocational upper-secondary education. Following the completion of compulsory education, approximately $98 \%$ of students continue their education at upper-secondary level. $40 \%$ of students enrol in general courses, more than $30 \%$ of students enrol in technical courses, while others (approximately 30\%) enrol in short vocational upper-secondary courses ${ }^{3}$.

In the next subsections, some selected inputs, outputs and outcomes of the education sector (particularly of secondary education) are presented.

\footnotetext{
2 See more detailed at: http://public.mzos.hr/Default.aspx?art=9443\&sec=2504 [cited 25 January 2012].

3 See more detailed at: http://www.mss.gov.si/en/areas_of_work/upper_secondary_education_in_slovenia/ [cited 28 January 2012].
} 


\subsection{Inputs}

In the European Union, the average annual cost per secondary school pupil (ISCED 2 to 4 ) is higher (PPS EUR 6,129) than that of primary school pupils (ISCED 1, PPS EUR 5,316). The average cost per student in tertiary education in the EU was almost twice as high as for primary pupils (PPS EUR 9,424). The disparities between countries tend to widen with the educational level involved. The cost of a pupil in primary education in public sector institutions ranges from PPS EUR 2,232 in Bulgaria to PPS EUR 10,746 in Luxembourg, whereas the cost of a student in public sector tertiary institutions ranges from PPS EUR 3,474 in Latvia to PPS EUR 23,103 in Cyprus. The figures for Denmark, Luxembourg, Slovenia, Slovakia and Croatia should be interpreted with caution because annual expenditure in public sector institutions cannot always be broken down fully by educational level (Eurostat 2012). The average annual cost per secondary school pupil (ISCED 2 to 4) in Croatia in 2008 is much lower (PPS EUR 3,700) than that in Slovenia (PPS EUR 5,500), which is less than half the average annual cost in the EU (Fig. 1).

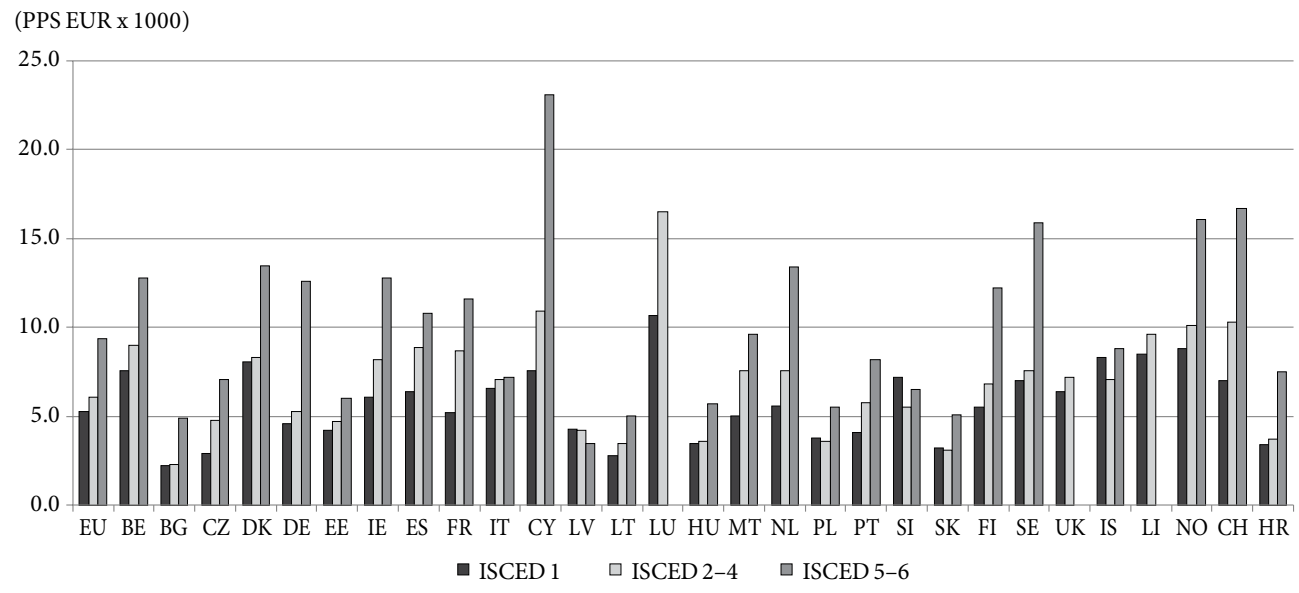

Fig. 1. Annual expenditure in public institutions per pupil/student and educational level (ISCED 1, 2-4 and 5-6), in PPS EUR (thousands), 2008

Source: Eurostat, UOE and national accounts statistics (data extracted June 2011).

In European countries, the employment status of fully qualified teachers for primary, lower secondary and upper-secondary levels of public sector education falls into two main categories. In more than half the countries studied, teachers are usually employed under open-ended contracts subject to general employment legislation. As public sector employees, teachers are employed at the local or school level, although they are usually directly employed by the

\footnotetext{
4 The International Standard Classification of Education (ISCED 1997) is an instrument suitable for compiling statistics on education internationally. The current version, ISCED 97, distinguishes seven levels of education: 1) Pre-primary (ISCED 0); 2) Primary (ISCED 1); 3) Lower secondary (ISCED 4); Upper secondary (ISCED 3); 5) Post-secondary non-tertiary (ISCED 4); 6) Tertiary (ISCED 5B - first stage); and 7) Tertiary (ISCED 5A +6 - second stage). For more details, see: http://www.uis.unesco.org/Education/Pages/isced-new-classification.aspx [cited 01 February 2011].
} 
school in which they teach. Elsewhere, teachers have the status of civil servants and in most countries they are appointed for life as career civil servants. Teachers who are civil servants are employed by public authorities at the central, regional or local level. Teachers working in public schools in Croatia and Slovenia are civil servants according to the countries' respective Civil Servants Acts, but they sign an employment contract with the head teacher since public schools are constituted as separate legal entities (Eurostat 2012).

\subsection{Outputs and outcomes}

In 2009, across Europe the average student teacher ratio in secondary schools was $12: 1^{5}$. Since 2000 , the student/teacher ratio has declined in two-thirds of the countries by an average of two pupils per teacher in primary education and by one pupil in secondary education. In lower secondary education, the greatest reduction (-6) is found in Slovenia and in Cyprus, Latvia and Lithuania (-5). In Croatia, the reduction was on average 1.8 pupils per teacher (Eurostat 2012).

It can be seen that the vast majority of 15 -year-old students who took part in the PISA ${ }^{6}$ 2009 survey spent less than two hours per week on homework or study at home per subject. In nine countries, more than $95 \%$ of students studied at home for less than two hours per week for each of the three analysed subjects (language, mathematics and science). Every PISA survey tests reading, mathematical and scientific literacy in terms of general competencies, that is, how well students can apply the knowledge and skills they have learned at school to real-life challenges (Eurostat 2012). In PISA 2006, students in Belgium (Flemish Community), the Netherlands, Poland and Slovenia reported they spent more time doing science homework than they did on the language of instruction. In 2009, this was not the case; mathematics and the language of instruction were the subjects on which students in all four countries/regions spent more time at home. In Croatia, according to PISA 2009 the majority of time students spent was on the language of instruction ${ }^{7}$.

Seventy-nine percent of young people in Europe aged 20-24 successfully completed upper-secondary education (ISCED 3) in 2010. This confirms the positive trend seen across Europe since 2000. In fact, the vast majority of countries report a rise in the number of young people holding at least an upper-secondary qualification over the last ten years. Several countries report percentages well above the European average: in the Czech Republic, Poland, Slovenia and Slovakia, about nine out of ten people between the ages of 20 and 24 hold at least an upper-secondary qualification. The highest level is found in Croatia, where the figure

\footnotetext{
5 The student/teacher ratio is the total number of students divided by the total number of teachers. It is a proxy for an outcome indicator such as the quality or effectiveness of secondary education.

6 PISA (Programme for International Student Assessment) is an international study which began in the year 2000. It aims to evaluate education systems worldwide by testing the skills and knowledge of 15-year-old students in participating countries/economies, at the age at which students in most countries are nearing the end of their compulsory time in school. PISA assesses youth outcomes in 3 domains: 1) reading literacy, 2) mathematical literacy, and 3) scientific literacy. PISA average score for every country is calculated according to this every three domains for each country. http://www.pisa.oecd.org/pages/0,3417,en_32252351_32235907_1_1_1_1_1,00.html [cited 03 February 2011].

7 OECD, PISA 2009 database - http://pisa2009.acer.edu.au/downloads.php [cited 03 February 2011].
} 
is over 95\% for this age group (Eurostat 2012). In spite of this positive trend, young people in some Eastern and Southern European countries faced a longer transition from school to work than the EU average for lower and upper-secondary education levels in 2009. This characteristic was particularly pronounced for people with at most a lower secondary education in Slovakia (24.3 months), Bulgaria (21.5 months) as well as in Poland (17 months), Cyprus (15.7 months), Slovenia (14.9 months), and Romania (12.5 months). No data are available for Croatia (Eurostat 2012).

\section{Empirical analysis}

\subsection{Methodology and data}

A common approach to measuring efficiency is based on the concept of the efficiency frontier (production possibility frontier). A popular non-parametric technique that has recently started to be commonly applied to (public) expenditure analysis is Data Envelopment Analysis (DEA). DEA is a non-parametric frontier estimation methodology originally developed by Farrell (1957) and popularised by Charnes et al. (1978). To measure efficiency, DEA is the choice here because it does not require us to specify the functional form or distributional forms for errors. In essence, it is more flexible than the parametric approach. Further, DEA has been extensively used to measure public sector efficiency in many countries by many researchers and, like Verma and Gavirneni (2006), Hauner (2007), Adam et al. (2011), Aristovnik (2013a, b), Aristovnik et al. (2013) point out, DEA has been so popular because it is easy to draw on diagrams and easy to calculate. Apart from the above reasons, DEA is chosen here because it is more reliable for measuring the technical efficiency as it can be applied to multi-input and multi-output variables.

As an example, consider a situation that has F DMUs, with each of them having $M$ inputs and $N$ outputs. Let $X_{l}^{f}$ be the level of input $l$ at DMU $f$ and let $Y_{l}^{f}$ be the level of out $k$ at DMU $f$. Without loss of generality, it will be assumed that the inputs and the outputs are defined in a manner such that lower inputs and higher outputs are considered better. The relative efficiency of $\mathrm{DMU} f$, denoted by $w_{f}$, is computed by solving the following linear program (Verma, Gavirneni 2006):

Subject to:

$$
\text { Maximize } w_{f}=\sum_{k=1}^{N} \beta_{k} Y_{k}^{f} \text {. }
$$

$$
\begin{gathered}
\sum_{l=1}^{M} \alpha_{l} X_{l}^{f} ; \\
\sum_{k=1}^{N} \beta_{k} Y_{k}^{f}-\sum_{l=1}^{M} \alpha_{l} X_{l}^{f} \leq 0 \quad \forall f=1,2, \ldots, F ; \\
\alpha_{l}, \beta_{k} \geq 0 .
\end{gathered}
$$

The basic idea in this approach is that, through the use of weights $\alpha$ and $\beta$, the sets of inputs and outputs are converted to a single "virtual input" and a single "virtual output". The ratio 
of the virtual output to the virtual input determines the efficiency associated with the DMU. In addition, when the efficiency of a DMU is being computed the weights are determined in such a way that its virtual input is set equal to 1 . The resulting virtual output for that DMU determines its relative efficiency. The technique is an attempt to find the "best" virtual unit for every real unit. If the virtual unit is better than the real one by either making more output with the same input or making a similar output with less input then we say that the real unit is inefficient. Thus, analysing the efficiency of $N$ real units becomes an analysis of $N$ linear programming problems.

In the majority of studies using DEA the data are analysed cross-sectionally, with each decision-making unit (DMU) - in this case the country - being observed only once. Nevertheless, data on DMUs are often available over multiple time periods. In such cases, it is possible to perform DEA over time where each DMU in each time period is treated as if it were a distinct DMU. However, in our case the data set for all the tests in the study includes average data for the 1999-2007 period (including PISA 2006 average scores) in order to evaluate long-term efficiency measures as the secondary education process is characterised by time lags in thirty-one EU (plus Croatia) and OECD countries. The program used for calculating the technical efficiencies is the DEAFrontier software. The data are provided by the OECD, UNESCO and the World Bank's World Development Indicators database.

The specification of the outputs and inputs is a crucial first step in DEA since the larger the number of outputs and inputs included in any DEA, the higher will be the expected proportion of efficient DMUs, and the greater will be the expected overall average efficiency (Chalos 1997). Common measures of teaching output in education used in previous studies are based on graduation and/or completion rates (Jafarov, Gunnarsson 2008), PISA scores (Afonso, St. Aubyn 2005; Jafarov, Gunnarsson 2008), pupil-teacher ratio and enrolment rate (Jafarov, Gunnarsson 2008). Moreover, the literature shows that the specification of the inputs is generally in the form of domestic (public or total) expenditure (in \% of GDP) (for education) or the number of hours in school (Afonso, St. Aubyn 2005). Nevertheless, these studies also demonstrate that DEA is an effective research tool for evaluating the efficiency of the education sector given the varying input mixes and types and numbers of outputs.

Hence, similar to the earlier empirical literature (particularly Afonso, St. Aubyn 2006a), in this analysis the data set to evaluate secondary education efficiency includes input/output/outcome data, i.e. (public) expenditure per student (secondary) (\% of GDP per capita), teacher-pupil ratio (secondary) or school enrolment, secondary (\% gross), school enrolment, tertiary (\% gross) and the PISA 2006 average score. Thirty-one countries are included in the analysis (selected EU (plus Croatia) and OECD countries). Different inputs and outputs/ outcomes have been tested in four models (Table 1).

\subsection{Empirical results}

This subsection shows the empirical application of the Data Envelopment Analysis (DEA) Summary statistics relating to the DEA analyses are displayed in Table 2. When looking at

\footnotetext{
${ }_{8}$ All the calculated results are available from the authors on request.
} 
Table 1. Input and output/outcome set for the DEA

\begin{tabular}{cll}
\hline Model & \multicolumn{1}{c}{ Inputs } & \multicolumn{1}{c}{ Outputs/Outcomes } \\
\hline I & $\begin{array}{l}\text { Expenditure per student, secondary } \\
\text { (\% of GDP per capita) }\end{array}$ & $\begin{array}{l}\text { School enrolment, secondary (\% gross) } \\
\text { PISA average }(2006)^{3} \\
\text { Teacher-pupil ratio, secondary }\end{array}$ \\
\hline II & $\begin{array}{l}\text { Expenditure per student, secondary } \\
\text { (\% of GDP per capita) } \\
\text { Teacher-pupil ratio, secondary }\end{array}$ & $\begin{array}{l}\text { School enrolment, secondary (\% gross) } \\
\text { PISA average (2006) }\end{array}$ \\
\hline III & Teacher-pupil ratio, secondary & $\begin{array}{l}\text { PISA average (2006) } \\
\text { School enrolment, tertiary (\% gross) }\end{array}$ \\
\hline IV & $\begin{array}{l}\text { School enrolment, secondary } \\
\text { (\% gross) }^{2}\end{array}$ & $\begin{array}{l}\text { PISA average }(2006) \\
\text { School enrolment, tertiary (\% gross) }\end{array}$ \\
\hline
\end{tabular}

Sources: ${ }^{1}$ UNESCO; ${ }^{2}$ World Bank; ${ }^{3}$ OECD.

Table 2. Summary statistics

\begin{tabular}{lcccccc}
\hline & Average & St. Dev. & Min. & Max. & SLO & CRO \\
\hline $\begin{array}{l}\text { Expenditure per } \\
\text { student, secondary } \\
\text { \% of GDP per capita) }\end{array}$ & 23.777895 & 4.7288054 & $\begin{array}{c}15.0563 \\
(\mathrm{ROM})\end{array}$ & $\begin{array}{c}36.011203 \\
(\mathrm{DEN})\end{array}$ & 27.66749 & 24.897357 \\
\hline $\begin{array}{l}\text { School enrolment, } \\
\text { secondary (\% gross) }\end{array}$ & 103.7513 & 12.73161 & $\begin{array}{c}79.74 \\
(\mathrm{MEX})\end{array}$ & $\begin{array}{c}133.0922 \\
(\mathrm{BEL})\end{array}$ & 100.48 & 88.3425 \\
\hline $\begin{array}{l}\text { School enrolment, } \\
\text { tertiary (\% gross) }\end{array}$ & 59.02336 & 15.04901 & $\begin{array}{c}22.7644 \\
(\mathrm{MEX})\end{array}$ & $\begin{array}{c}87.75778 \\
\text { (FIN) }\end{array}$ & 69.51333 & 37.8975 \\
\hline PISA average (2006) & 490.3095 & 32.99171 & $\begin{array}{c}408.601 \\
(\mathrm{MEX})\end{array}$ & $\begin{array}{c}552,8498 \\
(\mathrm{FIN})\end{array}$ & 505.8935 & 479 \\
\hline $\begin{array}{l}\text { Teachers per 100 pupils. } \\
\text { Secondary }\end{array}$ & 9.0969 & 1.4873 & $\begin{array}{c}5.2672 \\
(\mathrm{MEX})\end{array}$ & $\begin{array}{c}12.0387 \\
(\mathrm{POL})\end{array}$ & 9.0954 & 9.4227 \\
\hline
\end{tabular}

Sources: World Bank 2010; UNESCO 2010; OECD 2010; own calculations.

the education results ${ }^{9}$ by using Model 1 (Table 1) and applying the DEA efficiency frontier technique to Slovenia, Croatia and a select group of EU/OECD countries to measure the efficiency of secondary education, ten countries are seen as the most efficient. These most efficient countries include Greece, Ireland, Slovakia and Romania, although their secondary expenditures per student (in \% of GDP) are very low and averaged out at less than $19 \%$ (the EU/OECD average is $23.8 \%$ in the considered period). One can also see that some countries come very close to the frontier (e.g. Denmark and Sweden), while other countries are further away and therefore less efficient (e.g. Italy and Portugal) (Table 3). Some less efficient countries should significantly decrease their input (secondary expenditure per student) (e.g. Denmark from $36.0 \%$ to $25.7 \%$ ) and/or increase their outputs/outcomes, i.e. school

\footnotetext{
9 All of the results relate to DEA with an output orientation, allowing for variable returns to scale (VRSTE). VRSTE is assumed to be the relevant model for analysis it is difficult to change one's scale of operation in the short run especially for higher education institutions. The assumption of VRSTE also appears appropriate given that the study includes countries of varying sizes. Moreover, an output orientation focuses on the amount by which output quantities can be proportionally increased without changing the input quantities used. Using an input orientation approach leads to similar efficiency results as those presented in the text.
} 
enrolment (e.g. Austria and Latvia), average PISA scores (e.g. Bulgaria and Denmark) and teacher-pupil ratio (e.g. Japan and Lithuania) in order to become efficient ${ }^{10}$. According to Model I, Slovenia is ranked $19^{\text {th }}$ (its benchmark countries are Finland and New Zealand) and should decrease its secondary expenditures per student (in \% of GDP) by about 2 percentage points and increase its average PISA scores by more than 10 points to become an efficient country. On the other hand, Croatia is only ranked $28^{\text {th }}$ and should increase its average PISA scores by almost 19 points to be located on the efficiency frontier.

In terms of the efficiency scores for Model II, again ten of the analysed countries are labelled as efficient (Table 3), although New Zealand and Poland are now replaced by Japan and Sweden in the efficient group. The average output efficiency score is 1.09119 , which means that the average country could increase its outputs/outcomes by around $9.1 \%$ if it were efficient. The worse performers are again Italy and Portugal with well above average secondary education expenditures and below average PISA scores (less than 490) and school enrolment (less than 103.6\%). Indeed, both countries should increase their outputs by more than $14.4 \%$ in order to become efficient. When comparing Slovenia and Croatia, the results of the DEA analysis for Model II again suggest a relatively high level of inefficiency in secondary education, particularly in Croatia. However, both countries have worse rankings, indicating the existence of significant room to rationalise public spending without sacrificing, while also potentially improving their secondary education outputs and outcomes (Table 3). With respect to individual performance indicators, Croatia ranks in the last quartile (Slovenia is in the third quartile) for secondary education school enrolment and in the last quartile (Slovenia is in the second) for average PISA scores. In order to become efficient, both countries should reduce their (above average) teacher-pupil ratio (by about 0.5 teacher per 100 pupils) and increase the school enrolment rate by 4.8 percentage points in Croatia and 8.7 percentage points in Slovenia.

Table 3. DEA results for public secondary education efficiency in selected OECD and EU (plus Croatia) countries

\begin{tabular}{clcccccccc}
\hline \multirow{2}{*}{ No. } & \multirow{2}{*}{ Country } & \multicolumn{2}{c}{ Model I } & \multicolumn{2}{c}{ Model II } & \multicolumn{2}{c}{ Model III } & \multicolumn{2}{c}{ Model IV } \\
\cline { 2 - 10 } & & VRSTE & Rank & VRSTE & Rank & VRSTE & Rank & VRSTE & Rank \\
\hline 1 & Austria & 1.06329 & 17 & 1.10092 & 26 & 1.10092 & 15 & 1.08414 & 14 \\
\hline 2 & Belgium & 1.00000 & 1 & 1.00000 & 1 & 1.07782 & 10 & 1.08288 & 13 \\
\hline 3 & Bulgaria & 1.06865 & 18 & 1.09144 & 24 & 1.32790 & 29 & 1.30686 & 31 \\
\hline 4 & Croatia & 1.11404 & 28 & 1.14205 & 29 & 1.15418 & 24 & 1.01889 & 4 \\
\hline 5 & Czech R. & 1.04964 & 14 & 1.06915 & 18 & 1.10171 & 16 & 1.06565 & 9 \\
\hline 6 & Denmark & 1.01937 & 11 & 1.03932 & 13 & 1.10320 & 17 & 1.10320 & 19 \\
\hline 7 & Estonia & 1.06238 & 16 & 1.05353 & 15 & 1.06237 & 8 & 1.05299 & 6 \\
\hline
\end{tabular}

\footnotetext{
10 The average output efficiency score for secondary education (Model I) is 1.090, meaning that the average country could increase its outputs/outcomes by about $9.0 \%$ if it were efficient. The results also confirm our expectations that new EU member states are less efficient than EU-15 states in secondary education.
} 
Continued Table 3

\begin{tabular}{|c|c|c|c|c|c|c|c|c|c|}
\hline \multirow{2}{*}{ No. } & \multirow{2}{*}{ Country } & \multicolumn{2}{|c|}{ Model I } & \multicolumn{2}{|c|}{ Model II } & \multicolumn{2}{|c|}{ Model III } & \multicolumn{2}{|c|}{ Model IV } \\
\hline & & VRSTE & Rank & VRSTE & Rank & VRSTE & Rank & VRSTE & Rank \\
\hline 8 & Finland & 1.00000 & 1 & 1.00000 & 1 & 1.00000 & 1 & 1.00000 & 1 \\
\hline 9 & France & 1.10143 & 26 & 1.06957 & 19 & 1.08887 & 13 & 1.11470 & 23 \\
\hline 10 & Greece & 1.00000 & 1 & 1.00000 & 1 & 1.19124 & 28 & 1.16980 & 30 \\
\hline 11 & Hungary & 1.07605 & 21 & 1.07402 & 21 & 1.12018 & 20 & 1.10369 & 20 \\
\hline 12 & Iceland & 1.05791 & 15 & 1.05832 & 16 & 1.11989 & 19 & 1.11130 & 22 \\
\hline 13 & Ireland & 1.00000 & 1 & 1.00000 & 1 & 1.08607 & 12 & 1.07857 & 12 \\
\hline 14 & Italy & 1.17293 & 31 & 1.15750 & 31 & 1.15750 & 27 & 1.15956 & 29 \\
\hline 15 & Japan & 1.02600 & 13 & 1.00000 & 1 & 1.00000 & 1 & 1.05373 & 7 \\
\hline 16 & Korea & 1.00000 & 1 & 1.00000 & 1 & 1.01351 & 5 & 1.00000 & 1 \\
\hline 17 & Latvia & 1.10043 & 25 & 1.11722 & 27 & 1.13990 & 23 & 1.11922 & 24 \\
\hline 18 & Lithuania & 1.08209 & 22 & 1.00000 & 1 & 1.00000 & 1 & 1.13076 & 25 \\
\hline 19 & Mexico & 1.10619 & 27 & 1.06962 & 20 & 1.32791 & 30 & 1.00000 & 1 \\
\hline 20 & Netherlands & 1.00000 & 1 & 1.00000 & 1 & 1.02583 & 6 & 1.06163 & 8 \\
\hline 21 & N. Zealand & 1.00000 & 1 & 1.00079 & 12 & 1.05411 & 7 & 1.05244 & 5 \\
\hline 22 & Norway & 1.09658 & 24 & 1.08237 & 23 & 1.08512 & 11 & 1.13126 & 26 \\
\hline 23 & Poland & 1.00000 & 1 & 1.04851 & 14 & 1.10506 & 18 & 1.08884 & 16 \\
\hline 24 & Portugal & 1.15753 & 30 & 1.14408 & 30 & 1.15467 & 25 & 1.15949 & 28 \\
\hline 25 & Romania & 1.00000 & 1 & 1.00000 & 1 & 1.33009 & 31 & 1.09676 & 18 \\
\hline 26 & Slovakia & 1.00000 & 1 & 1.00000 & 1 & 1.13924 & 22 & 1.06873 & 10 \\
\hline 27 & Slovenia & 1.06972 & 19 & 1.09258 & 25 & 1.09282 & 14 & 1.07670 & 11 \\
\hline 28 & Spain & 1.07095 & 20 & 1.07475 & 22 & 1.15666 & 26 & 1.15641 & 27 \\
\hline 29 & Sweden & 1.02507 & 12 & 1.00000 & 1 & 1.00000 & 1 & 1.09620 & 17 \\
\hline 30 & UK & 1.08686 & 23 & 1.06297 & 17 & 1.06297 & 9 & 1.08648 & 15 \\
\hline 31 & USA & 1.12153 & 29 & 1.12466 & 28 & 1.12448 & 21 & 1.10489 & 21 \\
\hline & EU15 average & 1.07732 & & 1.08030 & & 1.10991 & & 1.10408 & \\
\hline & $\begin{array}{l}\text { New EU } \\
\text { member states }\end{array}$ & 1.10027 & & 1.09059 & & 1.13409 & & 1.13274 & \\
\hline & $\begin{array}{l}\text { Non-EU } \\
\text { average }\end{array}$ & 1.08489 & & 1.08432 & & 1.12436 & & 1.10715 & \\
\hline
\end{tabular}

\begin{tabular}{|c|c|c|c|c|}
\hline $\begin{array}{l}\text { Number of efficient } \\
\text { countries }\end{array}$ & 10 & 10 & 4 & 3 \\
\hline Mean & 1.09030 & 1.09119 & 1.12755 & 1.11390 \\
\hline Std. dev. & 0.05071 & 0.051077 & 0.088666 & 0.060124 \\
\hline
\end{tabular}

Note: Relative efficiency scores (Models I-IV; see Table 1). Thirty-one countries are included in the analysis (EU-27, OECD and Croatia). Slovenia and Croatia are presented in italic.

Sources: World Bank 2010; UNESCO 2010; OECD 2010; own calculations. 
When testing the efficiency of secondary education with Model III, only four of the thirtyone countries analysed within the formulation for secondary education presented in Table 3 are estimated as efficient. These countries are Finland, Japan, Lithuania and Sweden. Other countries under consideration could improve their efficiency scores by decreasing their input (teacher-pupil ratio), in particular in Poland (by about 3.5 teachers per 100 pupils) and Czech Republic (by about 1.7). However, even more importantly, a significant increase in outputs/ outcomes is needed in the form of school enrolment (tertiary) (in particular in Mexico and Czech Republic) and in the form of average PISA scores (in the USA and the Republic of Korea). In general, the output/outcome scores could on average be almost $13 \%$ higher. Similar to the previous model, Slovenia and Croatia are classified (in Model III) in the second and last quartiles, respectively. These DEA ranks also suggest that Slovenia's and Croatia's efficiency outputs/outcomes in secondary education should respectively be $9.3 \%$ and $15.4 \%$ higher than those under efficient conditions. Indeed, both countries should significantly improve their school enrolment (tertiary) to become efficient (Croatia by 44 percentage points, Slovenia by almost 12 percentage points).

In the final efficiency model (Model IV), only three countries (Finland, Korea and Mexico) are found technically efficient under VRSTE. However, Mexico is found to be efficient due to its extremely low (secondary) enrolment rate (79.74) and therefore this result should be interpreted with caution. The worst efficiency performers are Bulgaria and Greece due to their relatively poor average PISA scores (in both Bulgaria (416) and Greece (464)) and school enrolment rate (tertiary) (in Bulgaria (43.7\%)). The results of the model also show Croatia becoming highly efficient in comparison to Slovenia. This efficiency outcome is a result of its relatively low level of input, i.e. its (secondary) school enrolment rate (88.3\%) in Croatia. Nevertheless, similar to Model III, the DEA analysis shows that both countries should significantly increase their output (tertiary school enrolment rate) if they are to be efficient. The best benchmark countries for these two countries are Finland and the Republic of Korea, with the former country showing the highest (tertiary) school enrolment rate and the highest result of average PISA scores among the selected group of countries (Table 3).

To summarise, the presented empirical analysis makes it obvious that the secondary education sector in many of the considered countries suffers from relatively low technical efficiency, including in Slovenia and Croatia. The inefficiency is particularly evident in selected new EU member states (plus Croatia) and some less developed OECD members, i.e. emerging market economies (Table 4). However, contrary to our expectations, some highly developed countries such as the USA and Norway also have poor efficiency results. The empirical results also show that Slovenia and Croatia are ranked in the third and last quartiles (considering all four models), respectively, reflecting relatively high levels of inefficiency in their secondary education. Obviously, both countries use too many scarce public resources to produce relatively average (in Slovenia) or even below average (in Croatia) output/outcome. Therefore, taking advantage of the significant room to rationalise public secondary education spending without sacrificing, while also redirecting resources to the tertiary education sector, is recommended for both countries ${ }^{11}$.

\footnotetext{
${ }^{11}$ For instance, Slovenia is the only OECD country where spending per student at the tertiary level is less than that at lower levels of education (OECD 2011).
} 
Table 4. The relative efficiency of secondary education system in selected OECD and EU (plus Croatia) countries (Distribution by quartiles of the ranking of efficiency scores in all four models)

\begin{tabular}{llll}
\hline I quartile & II quartile & III quartile & IV quartile \\
\hline Finland & Slovakia & UK & Norway \\
Korea & Estonia & Slovenia & Croatia \\
Netherlands & Lithuania & Austria & Spain \\
Japan & Poland & Iceland & Latvia \\
Belgium & Romania & Mexico & USA \\
New Zealand & Czech Republic & France & Bulgaria \\
Ireland & Denmark & Hungary & Portugal \\
Sweden & Greece & & Italy \\
\hline
\end{tabular}

Note: Relative efficiency scores (Models I-IV; see Table 1). Thirty-one countries are included in the analysis (EU-27, OECD and Croatia). Slovenia and Croatia are presented in italic.

Sources: World Bank 2010; UNESCO 2010; OECD 2010; own calculations.

Speaking about the efficiency of secondary education in Croatia and Slovenia, it can be also concluded that both countries appear to perform inefficiently due to their high spending, but Croatia is also weaker in its outcomes than Slovenia. This low ranking of Croatian secondary education is due to the low enrolment rates and relatively low PISA scores (in mathematics). For example, Estonia, Poland, Slovakia and Latvia have lower education expenditure but better PISA 2009 results than Croatia. Namely, the average Croatian PISA result is below the expected value for a given level of public spending on education. Average class sizes in secondary education are comparatively small. In addition, Slovenian schools employ the highest number of professional support staff per pupil in the OECD (OECD 2011).

\section{Conclusions}

The total public expenditure in almost all European countries allocated to secondary education represents a greater proportion of GDP than spending on any other educational levels. Therefore, the measurement of the efficiency of secondary education is particularly important. As cross-country analysis in measuring efficiency of secondary education sector are uncommon for policy makers analysis, so we apply it. The most existing studies indicate that DEA is an effective research tool for evaluating efficiency of the education sector given the varying input mixes and types and numbers of outputs. Consequently, different inputs and outputs/outcomes have been tested in four models of DEA analyses. According to the empirical results, Slovenia and Croatia suffer from relatively low technical efficiency in their secondary education as they are only ranked in the third and last quartiles among thirty-one $\mathrm{OECD/EU}$ countries, respectively. The inefficiency is particularly problematic in Croatia where the poor results mainly stem from low enrolment rates (secondary and tertiary) and low PISA scores. On the other hand, in Slovenia the relatively good output/outcome is achieved at relatively higher costs. Indeed, public spending on secondary education is relatively high in both countries, particularly in Slovenia, without achieving respectively better outputs/outcomes than other comparable states. Therefore, both countries should pursue a number of initiatives to enhance the efficiency of their secondary education sector. In this respect, the secondary education system in both countries should be modernised to reduce 
operating costs by merging and closing selected schools that serve too few students, and extending catchment areas, while taking other socio-economic considerations into account. Surplus teaching and non-teaching staff should be rationalised by not replacing retiring staff in full. Indeed, reducing the number of secondary teachers through natural attrition and implementing a selective hiring freeze on new teachers is needed in the future. In this sense, taking advantage of the significant scope to rationalise public secondary education spending without sacrificing outcome, while also redirecting resources to the tertiary education sector is recommended for both countries.

Nevertheless, at least three caveats should be noted when we measure the efficiency of the secondary education sector and they should be taken into consideration when interpreting the presented results. Firstly, the applications of the presented techniques are hampered by a lack of suitable data to support those techniques. Quality data are needed because the techniques available to measure efficiency are sensitive to outliers and may be influenced by exogenous factors. Indeed, the substantial inefficiency found might simply be a reflection of environmental factors (such as climate, socio-economic background etc.). This also suggests the need to apply a combination of techniques to measure efficiency and effectiveness. Secondly, the precise definition used of inputs, outputs and outcomes might significantly influence the results. Finally, it seems important to bear in mind that, when using a non-parametric approach and despite DEA being an established and valid methodology, differences across countries are not statistically assessed, which may be considered a further limitation of such methodology.

\section{References}

Adam, A.; Delis, M.; Kammas, P. 2011. Public sector efficiency: leveling the playing field between OECD countries, Public Choice 146(1-2): 163-183. http://dx.doi.org/10.1007/s11127-009-9588-7

Afonso, A.; Schuknecht, L.; Tanzi, V. 2005. Public sector efficiency: an international comparison, Public Choice 123(3-4): 321-347. http://dx.doi.org/10.1007/s11127-005-7165-2

Afonso, A.; St. Aubyn, M. 2005. Non-parametric approaches to education and health efficiency in OECD countries, Journal of Applied Economics 8(2): 227-246.

Afonso, A.; St. Aubyn, M. 2006a. Cross-country efficiency of secondary education provision: a semi-parametric analysis with non-discretionary inputs, Economic Modelling 23(3): 476-491. http://dx.doi.org/10.1016/j.econmod.2006.02.003

Afonso, A.; St. Aubyn, M. 2006b. Relative efficiency of health provision: a DEA approach with non-discretionary inputs, ISEG-UTL, Department of Economics Working Paper 33/2006/DE/UECE.

Afonso, A.; Schuknecht, L.; Tanzi, V. 2006. Public sector efficiency: evidence for new EU member states and emerging markets, European Central Bank, Working Paper Series. European Central Bank: Frankfurt. $581 \mathrm{p}$.

Afonso, A.; Schuknecht, L.; Tanzi, V. 2008. Income distribution determinants and public spending efficiency, Working Paper Series. European Central Bank: Frankfurt. 861 p.

Aristovnik, A. 2012a. The relative efficiency of education and R\&D expenditures in the new EU member states, Journal of Business Economics and Management 13(5): 832-848.

http://dx.doi.org/10.3846/16111699.2011.620167

Aristovnik, A. 2012b. Measuring relative efficiency in health and education sector: the case of East European countries, Actual Problems of Economics 10(136): 305-314. 
Aristovnik, A. 2013a. ICT expenditures and education outputs/outcomes in selected developed countries: an assessment of relative efficiency, Campus-Wide Information Systems 30(3): 222-230. http://dx.doi.org/10.1108/10650741311330401

Aristovnik, A. 2013b. Technical efficiency of primary education: a comparative analysis of EU and OECD countries, Metalurgia International 18(8): 285-288.

Aristovnik, A.; Seljak, J.; Mencinger, J. 2013. Relative efficiency of police directorates in Slovenia: a nonparametric analysis, Expert Systems with Applications 40(2): 820-827. http://dx.doi.org/10.1016/j.eswa.2012.08.027

Čadež, S. 2013. Social change, institutional pressure and knowledge creation: a bibliometric analysis, Expert Systems with Applications 40(17): 6885-6893. http://dx.doi.org/10.1016/j.eswa.2013.06.036

Castano, M. C.; Cabanda, E. 2007. Sources of efficiency and productivity growth in the Philippine State universities and colleges: a non-parametric approach, International Business \& Economics Research Journal 6(6): 79-90.

Chalos, P. 1997. An examination of budgetary inefficiency in education using data envelopment analysis, Financial Accountability \& Management 13(1): 55-69. http://dx.doi.org/10.1111/1468-0408.00026

Charnes, A.; Cooper, W.; Rhodes, E. 1978. Measuring efficiency of decision-making units, European Journal of Operational Research 2(6): 429-444. http://dx.doi.org/10.1016/0377-2217(78)90138-8

Chen, J.-K.; Chen, I.-S. 2011. Inno-Qual efficiency of higher education: empirical testing using data envelopment analysis, Expert Systems with Applications 38(3): 1823-1834. http://dx.doi.org/10.1016/j.eswa.2010.07.111

Cherchye, L.; De Witte, K.; Ooghe, E.; Nicaise, I. 2010. Efficiency and equity in private and public education: nonparametric comparison, European Journal of Operational Research 202(2): 563-573. http://dx.doi.org/10.1016/j.ejor.2009.06.015

Clements, B. 2002. How efficient is education spending in Europe?, European Review of Economics and Finance 1: 3-26.

Eurostat, 2012. Key data on education in Europe - 2012. European commission - Eurostat - Eurydice, Luxembourg.

Farrell, M. 1957. The measurement of productive efficiency, Journal of the Royal Statistical Society Series A (General) 120(3): 253-281. http://dx.doi.org/10.2307/2343100

Grosskopf, S.; Moutray, C. 2001. Evaluating performance in Chicago public high schools in the wake of decentralization, Economics of Education Review 20(1): 1-14. http://dx.doi.org/10.1016/S0272-7757(99)00065-5

Gupta, S.; Verhoeven, M. 2001. The efficiency of government expenditure experiences from Africa, Journal of Policy Modelling 23(4): 433-467. http://dx.doi.org/10.1016/S0161-8938(00)00036-3

Gunnarsson, V.; Mattina, T. 2007. Budget rigidity and expenditure efficiency in Slovenia, IMF Working Paper WP/07/131.

Hauner, D. 2007. Benchmarking the efficiency of public expenditure in the Russian Federation, IMF Working Paper WP/07/246.

Jafarov, E.; Gunnarsson, V. 2008. Government spending on health care and education in Croatia: efficiency and reform options, IMF Working Paper WP/08/136.

Johnes, J. 2006. Data envelopment analysis and its application to the measurement of efficiency in higher education, Economics of Education Review 25(3): 273-288. http://dx.doi.org/10.1016/j.econedurev.2005.02.005

Keseljevic, A. 2007. Social capital as factor of evolutionary changes within the economic theory of organization, Ekonomicky Casopis 55(1): 79-93.

Mandl, U.; Dierx, A.; Ilzkovitz, F. 2008. The effectiveness and efficiency of public spending, European Commission Economic Papers 31, February. 
Mencinger, J.; Aristovnik, A. 2013. Fiscal policy stance in the European Union: the impact of the euro, Inzinerine Ekonomika - Engineering Economics 24(1): 52-62.

Obadić, A.; Aristovnik, A. 2011. Relative efficiency of higher education in Croatia and Slovenia: an international comparison, Amfiteatru Economic 13(30): 362-376.

OECD. 2010. Education at Glance 2010. OECD Indicators.

OECD. 2011. Economic Surveys SLOVENIA - Overview, February 2011: 1-13.

Official Gazzette. 2007. Nacionalni program mjera za uvođenje obveznoga srednjoškolskoga obrazovanja; Narodne novine br.: 71.

Oganisjana, K.; Koke, T. 2012. Does competence-oriented higher education lead to students' competitiveness?, Inzinerine Ekonomika - Engineering Economics 23(1): 77-82.

St. Aubyn, M. 2003. Evaluating efficiency in the Portuguese education sector, Economia 26: 25-51.

Stukalina, Y. 2012. Addressing service quality issues in higher education: the educational environment evaluation from the students' perspective, Technological and Economic Development of Economy 18(1): 84-98. http://dx.doi.org/10.3846/20294913.2012.658099

Thieme, C.; Gimenez, V.; Prior, D. 2012. A comparative analysis of the efficiency of national education systems, Asia Pacific Education Review 13(1): 1-15. http://dx.doi.org/10.1007/s12564-011-9177-6

UNESCO. 2010. Data Centre [online], [cited 28 November 2011]. Available from Internet: http://www. uis.unesco.org/Education/Pages/default.aspx

Verbič, M.; Majcen, B.; Ivanova, O.; Čok, M. 2011. R\&D and economic growth in Slovenia: a dynamic general equilibrium approach with endogenous growth, Panoeconomicus 58(1): 67-89. http://dx.doi.org/10.2298/PAN1101067V

Verma, A.; Gavirneni, S. 2006. Measuring police efficiency in India: an application of data envelopment analysis, Policing: an International Journal of Police Strategies \& Management 29(1): 125-145.

World Bank. 2010. World Development Indicators [online], [cited 25 November 2011]. Available from Internet: data.worldbank.org/indicator

Aleksander ARISTOVNIK is an Associate Professor in the Department of Public Sector Economics at the Faculty of Administration (University of Ljubljana, Slovenia). He has published many professional and scientific articles in various domestic and recognized international publications (Eastern European Economics, Journal of Economics, Expert Systems with Applications, Transformations in Business and Economics, etc.), recently. He is also a member of various international associations and organisations (e.g. European Economic Association, Regional Studies Association, INFER). His areas of research interest encompass Public Sector Economics, International Economics, International Finance and Economics of the EU.

\begin{abstract}
Alka OBADIĆ is an Associate Professor in "Croatian Economy", "Employment Policies", "Clusters and competitivenss" and "Macroeconomics", at the Department of Macroeconomics and Development, Faculty of Economics and Business, Zagreb, University of Zagreb, Croatia where she is also the Head of the graduate program in Economics. She has published independently and co-author two scientific books and two university textbooks and more than fifty scientific papers in the country and abroad. Her areas of research includes structural changes in the labor market, the unemployment problem, the economics of education, employment policy, fiscal policy, and the EU accession process.
\end{abstract}

